\title{
Toksisitas Merkuri (Hg) Pada Penambang Emas di Nagari Koto Tuo Sijunjung Sumbar
}

\author{
Herix Sonata MS ${ }^{1}$, Merry Thressia ${ }^{2}$, Dewi Yudiana Shinta ${ }^{3}$ \\ ${ }^{1}$ Institute Teknologi Padang. \\ ${ }^{2}$ Universitas EkaSakti Padang. \\ ${ }^{3}$ Universitas Perintis Padang.
}

*Correspondent email :dyshinta@ymail.com

Diterima: 08 Februari 2021 | Disetujui: 28 Februari 2021 | Diterbitkan: 28 Februari 2021

\begin{abstract}
Gold processing by amalgamation produces gold amalgam and waste mercury. Poor mercury waste management can pollute the environment. Ilegal gold miners are often found in West Sumatra. In the process of gold processing always use Hg for the purification of the gold. This study aims to determine the level of mercury $(\mathrm{Hg})$ in the gold miner's urine and see the long-working relationship. Mercury $(\mathrm{Hg})$ is a heavy metal grouped into groups having high toxicity levels. The use of mercury $(\mathrm{Hg})$ in the gold processing process can cause negative impact. Determination of mercury (Hg) with Atomic Absorption Spectrophotometer (SSA) method. The population of this research is gold miner worker in Nagari Koto Tuo Sijunjung as many as 3 people and also as sample. The instrument used in this research is a questionnaire and testing of urine specimen dilaboratorium with wet destruction method in research in.i Factors studied are the characteristics of respondents including age, and length of work. Sampling was done as much as $20 \mathrm{ml}$ of urine. Urine sample examination was done at Laboratory by using Wet Destruction method. The result of mercury $(\mathrm{Hg})$ examination in gold miner's urine was obtained by an average of $15.8 \mu \mathrm{g} / \mathrm{l}$ Mercury $(\mathrm{Hg})$ in urine with a threshold of $4 \mu \mathrm{g} / \mathrm{l}$. The benefit of this research is to provide an overview of the level of toxicity that occurs due to gold mining in illegal gold miners in Nagari Koto Tuo Sijunjung, West Sumatra.
\end{abstract}

Keywords: mercury (Hg); urine; gold miners in Nagari Koto Tuo

Potensi produksi pertambangan emas di Indonesia termasuk dalam kategori cukup besar. Total produksi selama tahun 1990 - 2011 adalah sebesar 2501849,73 kg pertahun sedangkan produksi tambang emas rata - rata sebesar $113720,4423 \mathrm{~kg}$ pertahun (Rumatoras.H, 2016). Merkuri (Hg) merupakan salah satu jenis logam berat yang banyak ditemukan di alam dan tersebar dalam batu-batuan, biji tambang, tanah, air dan udara sebagai senyawa anorganik dan organic (Sumantri.A, 2014). Penggunaan merkuri (Hg) khususnya penambangan emas untuk memisahkan emas dari butiran pasir melalui proses amalgamasi.

Proses amalgamasi yang dilakukan dalam proses pengolahan emas dapat menimbulkan toksisitas bagi penambang dan penduduk sekitar penambangan. Pada saat proses tersebut terjadi proses inhalasi atau proses masuknya merkuri ke dalam tubuh terutama melalui paru - paru dalam bentuk uap. Sekitar $80 \%$ uap merkuri yang terinhalasi akan diabsorbsi melalui pernafasan, saluran cerna dan kulit. Setelah diabsorbsi di jaringan, merkuri akan mengalami oksidasi membentuk merkuri divalent yang dibantu enzim katalase. Inhalasi merkuri dalam bentuk uap akan diabsorbsi melalui sel darah merah, sebagian akan menuju otak yang kemudian diakumulasi di dalam jaringan.

Merkuri termasuk logam berat yang dikategorikan ke dalam limbah Bahan Berbahaya dan Beracun (B3) karena bersifat racun dan persisten sehingga dapat membahayakan lingkungan hidup dan manusia (MENLH, 2013). Berdasarkan Undang-Undang Nomor 32 tahun 2009 tentang Perlindungan dan Pengelolaan Lingkungan Hidup pada pasal 69 jelas dikatakan bahwa setiap orang dilarang membuang limbah B3 ke media lingkungan termasuk badan sungai. Bila limbah B3 dibuang ke badan sungai tentu akan mencemari air sungai dan berbahaya bagi kesehatan masyarakat yang menggunakan air sungai tersebut sebagai air minum dan keperluan hidup lain (Soprima,M.,2015).

Kasus toksisitas merkuri yang paling dikenal adalah kasus Minamata. Pada tahun 1961, peneliti di Jepang menghubungkan kadar merkuri urin yang tinggi dengan penyakit Minamata yang misterius. Penyakit yang timbul pada masyarakat sekitar teluk Minamata akibat merkuri yaitu tremor, gangguang sensoris, ataksia, dan penyemprotan lapang pandang(Sumantri.A, 2014 ). 
Pekerja tersebut melakukan penambangan emas secara tradisional. Mereka melakukan penambangan tanpa menggunakan APD yang lengkap. Penambang emas tersebut sangat mudah terpapar Merkuri (Hg) pada saat proses penyaringan. Pada proses penyaringan Merkuri (Hg) masuk kedalam tubuh melalui kulit disebabkan proses penyaringan dengan pencampuran Merkuri (Hg).

Kandungan Merkuri $(\mathrm{Hg})$ dalam urin salah satu indicator yang digunakan untuk menilai sejauh mana kontaminasi merkuri yang terjadi pada penambang emas karena urin dapat mengakumulasi merkuri dalam jangka waktu yang lama. Ambang batas kadar merkuri dalam urin maksimal $4 \mu \mathrm{g} / 1$ (Andri $\mathrm{DH}$, dkk 2011)

Kontak yang terjadi antara merkuri dengan individu dapat melalui inhalasi kulit atau saluran cerna (tertelan) yang kemudian diabsorbsi (diserap)untuk kemudian didistribusikan oleh darah keseluruh tubuh dan nantinya akan mengalami proses ekskresi melalui beberapa rute yaitu lewat urine,keringat air susu,air liur feses,kuku dan rambut (Hartono,W,2003).

Lama seseorang bekerja (dalam satuan tahun) dan selama itu pula orang tersebut terpajan merkuri. Pengaruh masa kerja dengan kada rmerkuri berkaitan dengan akumulasi merkuri dalam tubuh para pekerja, semakin sering seseorang terpapar dengan merkuri maka akan semakin tinggi pula kadar merkuri dalam tubuhnya. Pekerja tambang emas berisiko tinggi mengalami keracunan merkuri karena kontak langsung yang terjadi pada saat proses amalgamasi melalui kulit da ninhalasi, paparan melalui inhalasi akan menyebabkan terjadinya penyerapan merkuri hingga 80\% dalam tubuh (Indah M.F, 2020).

Keracunan merkuri $(\mathrm{Hg})$ sangat beresiko tinggi pada penambang emas tradisional. Keracunan merkuri $(\mathrm{Hg})$. tergantung pada bentuk merkuri $(\mathrm{Hg})$, jalannya masuk ke dalam tubuh manusia dan lamanya berkembang. Kadar merkuri $(\mathrm{Hg})$ dalam urin merkuri salah satu indicator yang digunakan untuk menilai sejauhmana kontaminasi merkuri $(\mathrm{Hg})$ yang terjadi pada penambang emas karena urin dapat mengakumulasi merkuri dalam jangka waktu yang lama. Penelitian ini bertujuan untuk mengetahui kadar merkuri $(\mathrm{Hg})$ didalam urine penambang emas dan melihat hubungan lama bekerjanya. Manfaat penelitian ini untuk memperikan gambaran tingkat toksisitas yang terjadi akibat penambangan emas pada penambang emas illegal di Nagari Koto Tuo Sijunjung Sumbar.

\section{METODE PENELITIAN}

Penelitian ini merupakan jenis penelitian deskriptif eksperimental yaitu melakukan percobaan yang bertujuan untuk mengetahui kadar merkuri $(\mathrm{Hg})$ di dalam urine pekerja penambang emas dan melihat hubungan dengan lama terpapar dengan merkuri. Penetapan kadar merkuri (Hg) dengan metode Spektrofotometer Serapan Atom SSA. Penelitian ini dilakukan di Labkesda Padang dan pengambilan sampel dilakukan di Koto Tuo,Sijunjung.

Populasi dalam penelitian ini adalah seluruh pekerja penambang emas di Nagari Koto Tuo, Sijunjung. Jumlah pekerja penambang emas yang diteliti sebanyak 3 orang. Sampel yang digunakan dalam penelitian ini adalah Urine pekerja penambang emas di Nagari Koto Tuo yang masih aktif bekerja.

Pengumpulan data dapat dilakukan dengan melakukan wawancara, observasi, dan pengukuran terhadap kadar merkuri pada urin pekerja penambang emas di Nagari Koto tuo, Sijunjung

Alat yang digunakan yaitu Hot plate, labu ukur, gelas kimia, Pipet tetes, gelas ukur, bola hisap, pipet takar, corong, AAS, kotak pendingin, botol sampel, kertas saring.

Bahan yang digunakan yaitu Aquadest, tissu, $\mathrm{HNO}_{3}$ Pekat, standar $\mathrm{Hg}$,larutan kalium permanganat $\mathrm{KMnO}_{4}$, Asam Sulfat $\mathrm{H}_{2} \mathrm{SO}_{4}$, Larutan Kalium persulfat $\mathrm{K}_{2} \mathrm{~S}_{2} \mathrm{O}_{8}$.

\section{Preparasi sampel}

Urine yang diperoleh yaitu urine pagi sebanyak $20 \mathrm{ml}$ disimpan dibotol sampel yang ditutup dengan rapat. Urine dimasukkan kedalam gelas ukur lalu ditambahkan dengan larutan $\mathrm{HNO}_{3}$ kemudian lakukan pemanasan dengan hot plate dan dilakukan dengen pengenceran aquades.

Atur panjang gelombang menjadi $253,7 \mathrm{~nm}$, instal absorption cell dan menyeleraskannya pada cahaya untuk memberikan transmisi yang maksimum. Hubungkan peralatan terkait ke absorption cell dengan tabung kaca atau plastic vinyl, .Hidupkan dan sesuaikan laju alur udara sampai 2L/menit. 


\section{SEHATI}

Vol 1, No 1, Februari 2021, p. 33-38

Jurnal Kesehatan

Standarisasi

Bagi $100 \mathrm{~mL}$ dari masing-masing 1,2 dan $5 \mu \mathrm{g} / \mathrm{L}$ larutan standar $\mathrm{Hg}$ dan $100 \mathrm{Ml}$ air ke labu Erlenmeyer $250 \mathrm{ml}$ konsentrai $\mathrm{H}_{2} \mathrm{SO}_{4}$ dan 2,5 $\mathrm{ml}$ konsentrasi $\mathrm{HNO}_{3}$ ke dalam masing-masing tabung dan diamkan sekitar $15 \mathrm{ml}$ larutan $\mathrm{KMnO}_{4}$ kedalam masing-masing tabung dan diamkan selama 15 menittambahkan $8 \mathrm{ml}$ larutan $\mathrm{K}_{2} \mathrm{~S}_{2} \mathrm{O}_{8}$ dan panaskan selama 2 jam pada temperature $95^{\circ} \mathrm{C}$.tambahkan larutan $\mathrm{Nacl}$-hidroksil-amin dan $5 \mathrm{ml}$ larutan $\mathrm{SnCl}_{2}$ atau $\mathrm{SnSO}_{4}$, kemudian pasang aerasi . Hg yang diuapkan dibawa ke absorption cell.keluarkan sumbat penghambat dari labu reaksi dang anti dengan labu yang berisi air.lakukan flush system dan jalankan standar selanjutnya dengan cara yang sama ,kemudian buat kurva standarnya.

\section{Analisis sampel}

Masukkan $100 \mathrm{ml}$ larutan sampel kedalam labu reaksi yang berisi $100 \mathrm{ml}$ kandungan $5 \mu \mathrm{g}$ $\mathrm{Hg} / \mathrm{L}$.lakukan seperti pada point b.total Hg pada sampel akan diserap dan di deteksi kadarnya dengan AAS.

\section{HASIL}

Dari hasil penelitian yang telah dilakukan pada penambang emas dengan analisis kadar Hg pada urin penambang emas di nagari Koto tuo Sijunjung.

Tabel 1. Hasil Pengukuran Merkuri urine penambang emas berdasarkan umur dan lama bekerja

\begin{tabular}{lcccc}
\hline No & Nama & Umur & Masa Kerja & Kadar Merkuri dalam urine \\
\hline 1 & $\mathrm{~T}$ & 45 & 20 & $26,03 \mu \mathrm{g} / 1$ \\
2 & $\mathrm{~A}$ & 35 & 15 & $19,82 \mu \mathrm{g} / 1$ \\
3 & $\mathrm{~N}$ & 25 & 5 & $1,53 \mu \mathrm{g} / 1$ \\
\hline
\end{tabular}

Berdasarkan tabel 1 , diatas responden $\mathrm{T}$ yang masa bekerjanya selama 20 tahun memiliki kadar merkuri $26,03 \mu \mathrm{g} / 1$ dan responden A yang masa bekerjanya selama 15 tahun memiliki kadar merkuri sebanyak $19,82 \mu \mathrm{g} / 1$ sedangkan responden $\mathrm{N}$ yang masa bekerjanya selama 5 tahun memiliki kadar lebih sedikit sebanyak $1,53 \mu \mathrm{g} / 1$.

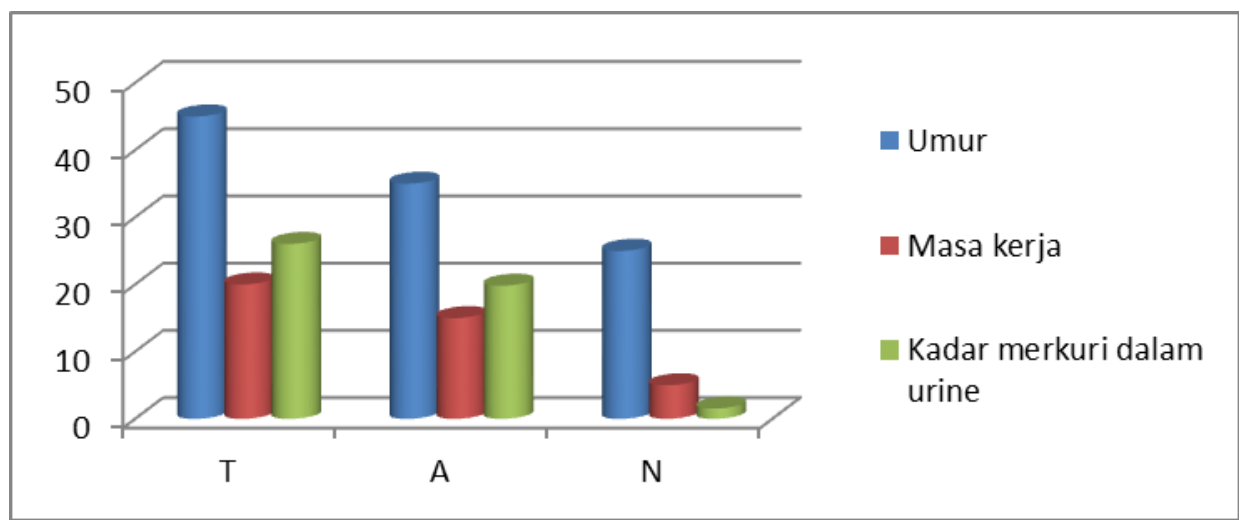

Gambar 1. Garfik Hubungan masa kerja, umur dengan kadar Hg dalam darah

Berdasarkan grafik 1 diatas kadar merkuri paling tinggi yaitu responden $\mathrm{T}$ yang masa bekerjanya 20 tahun,dan responden A yang masa bekerjanya 15 tahun dan yang paling rendah kadar merkurinya yaitu responden $\mathrm{N}$ dengan masa kerjanya 5 tahun.

Tabel 2. Distribusi Merkuri dalam urin masyarakat koto tuo sijunjung

\begin{tabular}{ccc}
\hline Variabel & Rata-rata & Standar Deviasi \\
\hline Kadar Merkuri dalam Urine & 15,8 & 12,73 \\
\hline
\end{tabular}

Dari hasil pencarian didapat Standar Deviasi yaitu 12,73 dan Rata-rata 15,8. 
Tabel 3. Hasil Pengolahan Data

\begin{tabular}{|c|c|c|c|c|}
\hline No & $\mathbf{x}_{\mathbf{i}}$ & $\bar{x}$ & $\left(\mathrm{x}_{\mathrm{i}}-{ }^{\bar{x}}\right)$ & $\left(\mathrm{x}_{\mathrm{i}}-\bar{x}\right)^{2}$ \\
\hline 1 & 26,03 & 15,7 & 10,33 & 106,7089 \\
\hline 2 & 19,82 & 15,7 & 4,12 & 16,9744 \\
\hline 3 & 1,53 & 15,7 & 14,17 & $\begin{array}{l}200,7889 \\
3244722\end{array}$ \\
\hline
\end{tabular}

$$
S=\sqrt{\frac{\sum_{i=1}^{n}\left(X_{i}-\bar{X}\right)^{2}}{n-1}}
$$

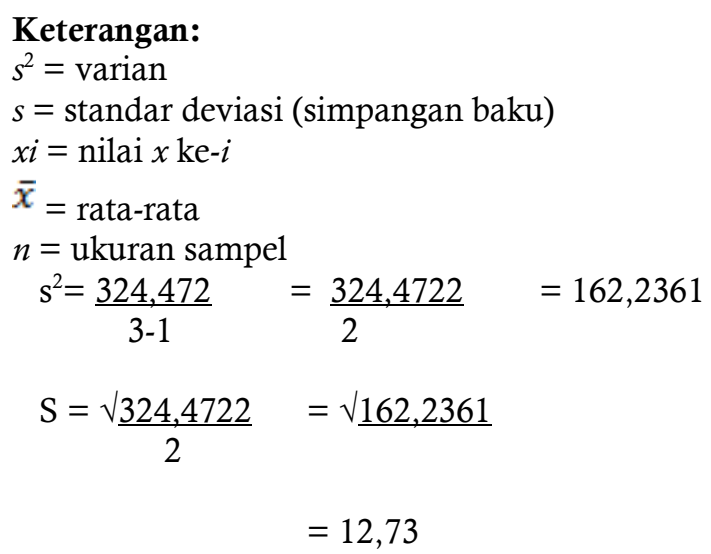

\section{PEMBAHASAN}

SSA (Spektrofotometer Serapan Atom) adalah salah satu metode yang pengukurannya berdasarkan penyerapan cahaya dengan panjang gelombang tertentu.Pada penelitian ini yang diperiksa adalah merkuri (Hg) yang mempunyai panjang gelombang yaitu $253,7 \mathrm{~nm}$.

Penelitian ini merupakan jenis penelitian deskriptif eksperimental yaitu melakukan percobaan yang bertujuan untuk mengetahui kadar merkuri $(\mathrm{Hg})$ di dalam urine pekerja penambang emas dan melihat hubungan lama bekerjanya.Penetapan kadar merkuri $(\mathrm{Hg})$ dengan metode Spektrofotometer Serapan Atom SSA.

Lama seseorang bekerja (dalam satuan tahun) dan selama itu pula orang tersebut terpapar merkuri. Pengaruh masa kerja dengan kadar merkuri berkaitan dengan akumulasi merkuri dalam tubuh pekerja, semakin sering seseorang terpapar dengan merkuri maka semakin tinggi pula kadar merkuri dalam tubuhnya (Asiah.N,2015).

Dari hasil penelitian yang didapatkan responden T bekerja selama 20 tahun maka merkuri yang terkandung didalam tubuhnya sebanyak $26,03 \mu \mathrm{g} / 1$ dan responden A yang bekerja selama 15 tahun merkuri yang ada ditubuhnya terdapat $19,82 \mu \mathrm{g} / 1$ sedangkan responden $\mathrm{N}$ yang bekerja hanya 5 tahun merkuri yang ada ditubuhnya adalah $1,53 \mu \mathrm{g} / 1$. Semakin lama seseorang tersebut bekerja maka semakin banyak merkuri terdapat dalam tubuhnya.

Proses masuknya merkuri kedalam tubuh terutama melalui paru-paru dalam bentuk uap atau debu. Sekitar $80 \%$ uap merkuri yang terinhalasi akan diabsorbsi. Absorbsi merkuri logam yang tertelan dari saluran cerna hanya dalam jumlah kecil yang dapat diabaikan, sedangkan senyawa merkuri larut air mudah diabsorbsi.Beberapa senyawa merkuri organic dan anorganik dapat diabsorbsi melalui kulit.Biotransformasi unsur merkuri yang diabsorbsi dengan cepat dioksidasi menjadi ion $\mathrm{Hg}^{2+}$ yang memiliki afmitas berikatan dengan substrat-substrat yang kaya gugus tersebut.Merkuri ditemukan dalam ginjal (terikat pada metalotionen) dan hati.Merkuri dapat melewati darah-otak dan plasenta.Metil merkuri mempunyai afmitas yang kuat terhadap otak. Sekitar $90 \%$ merkuri darah terdapat dalam 
SEHATI

Jurnal Kesehatan
Vol 1, No 1, Februari 2021, p. 33-38

e-ISSN : 2775-6963 | p-ISSN : 2775-6955

eritrosit.Metabolisme senyawa alkil merkuri serupa dengan metobolisme merkuri logam atau senyawa anorganiknya.Senyawa fenil dan metoksietil merkuri di metabolisme dengan lambat.

Merkuri yang ada diurine terjadi karena sudah mengalami proses absorbsi dan dilanjutkan dengan proses Ekskresi. Unsur merkuri dan senyawa anorganiknya dieliminasi lebih banyak melalui kemih dari pada feses, karena proses ekskresi sangat dipengaruhi oleh waktu. Waktu yang dibutuhkan untuk ekskresi hampir mencapai separuh kadar yang ada dalam tubuh. Waktu paruh merkuri sekitar 60 hari, dan pengeluaran merkuri dalam bentuk urine memiliki paruh waktu 40-60 hari.

Merkuri memiliki pengaruh toksisitas pada SSP (Sistem Saluran Pencernaan) dan ginjal terutama akibat merkuri terakumulasi. Organ utama yang terkena pada paparan kronik oleh elemen merkuri dan organomerkuri adalah SSP (Sistem Saluran Pencernaan). Sedangkan garam merkuri akan berpengruh pada kerusakan ginjal. Merkuri juga berpengaruh terhadap system syaraf akibat dari pemajanan uap elemen merkuri dan metil merkuri karena senyawa ini mampu menembus blood brain barrier dan juga mengakibatkan kerusakan otak yang irreversible sehingga mengakibatkan kelumpuhan permanen. Metilmerkuri yang masuk kedalam pencernaan akan memperlambat SSP (Sistem Saraf Pusat) yang mungkin tidak dirasakan pada pemajanan setelah beberapa bulan sebagai gejala pertama sering tidak spesifik seperti malas, pandangan kabur dan ketulian.

Apabila terjadi akumulasi pada ginjal yang diakibatkan oleh masuknya garam inorganic melalui SSP akan menyebabkan naiknya permeabilitas epitel tubulus sehingga akan menurunkan kemampuan fungsi ginjal.

Kerusakan pada ginjal yang dapat menyebabkan kematian akibat gagal ginjal.Bentuk urin yang terkontaminasi dengan merkuri dapat diperhatikan bau air urin setelah pemakain krim merkuri, bau urin akan menjadi tajam. Orang yang pakai krim merkuri biasa nya merasakan sakit pinggang, bukan karena kelelahan tapi karena merkuri adalah logam berat yang menumpuk di ginjal. Ginjal itu ibarat nya saringan santan. Merkuri itu ibarat nya batu-batu kerikil, apabila ginjal disuruh saring logam berat seperti merkuri, lama-lama ginjal akan jebol (gagal ginjal). Bentuk urin yang tidak terkontaminasi dengan merkuri dapat diperhatikan bau urin khas seperti amonia. Hal ini sejalan dengan penelitian Lestarisa (2010) bahwa terdapat hubungan yang signifikan antara masa kerja dengan kadar merkuri dalam tubuh. Walaupun kadar merkuri dalam urin pekerja tambang emas masih dalam batas normal, harus diwaspadai karena masa kerja yang lama memungkinkan pekerja lebih lama terpapar dengan merkuri sehingga hal tersebut berpotensi untuk terjadi bioakumulasi di dalam tubuhnya. Menurut Darmono, 2009, Penggunaan merkuri dalam waktu lama menimbulkan dampak gangguan kesehatan bahkan sampai kematian. Dalam kesehatan kerja peristiwa keracunan dapat terjadi apabila terjadi kontak individu dengan merkuri baik melalui proses inhalasi, kontak kulit atau tertelan yang terlihat pada proses amalgamasi (Yanuar, 2000).

Apabila kadar merkuri dalam darah masyarakat terpajan merkuri lebih besar dari kadar merkuri normal dapat dikatakan berpotensi menimbulkan gangguan kesehatan. Gangguan kesehatan tersebut dapat berupa gangguan ginjal, autoimun, dan gejala-gejala neurologic. Gangguan tersebut adalah kesimpulan dari ulasan komprehensif yang dilakukan oleh WHO terhadap komunitas atau individu yang berhubungan dengan pemakaian merkuri pada pertambangan emas rakyat. Dengan ulasan tersebut dapat dikatakan masyarakat yang tinggal dekat dengan pertambangan emas rakyat juga berisiko terhadap munculnya gangguan kesehatan akibat pencemaran merkuri, apalagi penambang emas yang berkontak langsung dengan pemakaian merkuri (Soprima,M, 2015).

\section{KESIMPULAN}

Kesimpulan yang didapat, responden $\mathrm{T}$ bekerja selama 20 tahun maka merkuri yang terkandung didalam tubuhnya sebanyak $26,03 \mu \mathrm{g} / 1$ dan responden A yang bekerja selama 15 tahun merkuri yang ada ditubuhnya terdapat $19,82 \mu \mathrm{g} / 1$ sedangkan responden $\mathrm{N}$ yang bekerja hanya 5 tahun merkuri yang ada ditubuhnya adalah $1,53 \mu \mathrm{g} / 1$. Pengaruh masa kerja dengan kadar merkuri berkaitan dengan akumulasi merkuri dalam tubuh pekerja, semakin sering seseorang terpapar dengan merkuri maka semakin tinggi pula kadar merkuri dalam tubuhnya 


\section{DAFTAR PUSTAKA}

Andri DH, dkk, Kadar Merkuri Pada urine Masyarakat Disekitar Penambang EmasTanpa Ijin. Media Medika Indonesia 2011.Vol. 45.181-187.

Asiah.N, 2015, Pengaruh Lama Kerja Terhadap Kadar Merkuri (Hg) dalam Urin Pekerja Tambang Emas (Studi Kasus di Desa panton Luas Kecamatan Sawang Kabupaten Aceh Selatan), Jurnal Pendidikan Kimia, ISSN : 2085-3653, vol 7, no 2 Agustus 2015, hal 712.

Darmono. 2009. Farmasi Forensik dan Toksikologi. UI Press

Hartono, Wahyu. 2003. Faktor-faktor yang Berhubungan dengan Kadar Merkuri dalam Rambut pada Pekerja Laboratorium di Balai Laboratorium Kesehatan Bandar Lampung tahun 2003. Depok : tesis FKM UI

Indah.M.F,2020, Dampak Kualitas Aliran Sungai Terhadap Paparan Merkuri (Hg) pada Penambang Emas, Deepublish, Sleman Yogyakarta.

Lestarisa, dkk, 2010, Faktor-faktor Yang Berhubungan Dengan Keracunan Merkuri (Hg) Pada Penambang Emas Tanpa Ijin (PEI) di Kecamatan Kurun Kabupaten Gunung Mas Kalimantan Tengah. Jurnal Ekologi Kesehatan, 7(2):775-785.

Rumatoras.H, dkk,2016, Analisis Kadar Merkuri (Hg) Pada Rambut Penduduk desa Kayeli, Akibat Penambangan Emas Tanpa Ijin di Areal Gunung Botak, Kabupaten Buru Propinsi Maluku, Ind.J.Chem.res, 3, hal 290-294.

Soprima,M,dkk, 2015, Kajian Resiko Kesehatan masyarakat Akibat Pajanan merkuri pada penambang Emas Rakyat di Kabipaten Lebak Banten, Jurnal Ekologi Kesehatan, volume 14, no 4, desember 2015, hal 296-308.

Subandri, 2008. Kajian Beban Pencemaran Merkuri (Hg) Terhadap Air Sungai Menyuke Dan Gangguan Kesehatan Pada Penambang Sebagai Akibat Penambangan Emas Tanpa Izin (PETI) di Kecamatan Menyuke Kabupaten Landak Kalimantan Barat, Tesis, Magister Kesehatan Lingkungan Universitas Diponegoro, Semarang.

Sumantri,A, dkk, 2014, Logam Merkuri pada Pekerja Penambang Emas Tanpa Ijin, Jurnal Kesehatan Masyarakat Nasional, vol 8 no 8 Mei 2014, hal 398-403.

Widowati, W., Sastiono, A.,Jusuf, R., dan Raymond. 2008. Efek toksik logam "Pencegahan Dan Penanggulangan Pencemaran". Penerbit ANDI, Yogyakarta.

Yanuar, A. 2000. Toksisitas merkuri disekitar kita. Departemen Farmasi FMIPA Universitas Indonesia. Jakarta 